\title{
Miyelom, lenfoma, lösemi
}

\author{
Myeloma, lymphoma, leukemia
}

\author{
Bülent Erol, Emrah Çalışkan
}

Marmara Üniversitesi, Pendik Eğitim Araştırma Hastanesi, Ortopedi ve Travmatoloji Kliniği, İstanbul

\begin{abstract}
Miyelom ve lenfoma yuvarlak hücreli tümörler grubu içinde yer alan habis neoplazilerdir. Bu grupta yer alan lezyonlar matriks üretimi olmaksızın büyüyen indiferansiye yuvarlak hücrelerden oluşur. Miyelom kemiğin en sık primer habis tümörüdür. Kemik iliği kaynaklı miyelom genellikle erişkinlerde görülür ve 40 yaş üzeri kemik tümörlü her hastanın ayırıcı tanısında yer almalıdır. Lenfoma kemiği primer veya sekonder olarak etkileyebilir. Lenf nodu ve viseral tutulumla beraber giden sekonder kemik lenfoması göreceli olarak sık görülürken, primer habis lenfoma oldukça nadirdir. Başta Ewing sarkomu olmak üzere diğer habis yuvarlak hücreli tümörler ve osteomiyelit kemik lenfomasının ayırıcı tanısı içinde bulunur. Çocukluk çağının en sık kanseri olan akut lösemide kemik ve eklem tutulumu sık görülür. Kemik ağrısına eşlik eden sitopeni, ateş, kanama bulguları, hepatosplenomegali ve lenfadenopati gibi bulguları olan bir çocukta kemiğin lösemik infiltrasyonundan şüphelenilmesi gerekir.
\end{abstract}

Anahtar sözcülkler: multipl miyelom; kemik iliği tümörleri; lenfoma; lösemi
Myeloma and lymphoma are malignant round cell lesions. Round cell lesions are characterized by growth of undifferentiated round cells without matrix production. Myeloma is the most common primary malignant bone tumor. It is originated from bone marrow and seen mostly in adults. Myeloma should be included in differential diagnosis of all patients after 40 years old with bone tumors. Lymphoma can affect the bone primarily or secondarily. Secondary bone lymphoma which is associated with nodal and visceral involvement is more common than primary lymphoma of bone. Ewing sarcoma and other malignant round cell tumors and osteomyelitis should be included in the differential diagnosis of bone lymphoma. Acute leukemia is the most common cancer of childhood and frequently associated with bone and joint involvement. Leukemic infiltration should be suspected in a child who presented with bone pain and associated symptoms such as cytopenia, fever, bleeding manifestations, hepatosplenomegaly and lympadenopathy.

Key words: multiple myeloma; bone marrow neoplasms; lymphoma; leukemia

\section{MULTIPL MIYELOM (PLAZMASITOM)}

Miyelom aktif kırmızı kemik iliğinden köken alan bir tümördür. Kemiğin en sık primer habis tümörüdür ve primer kemik kanserlerinin \%40'ından fazlasını oluşturur. ${ }^{[1]}$ Miyelomun tanısı çoğu zaman kemik iliği biyopsisi ile konur, kemik iliği mikroçevresinde lokal değişiklikler görülür. Miyelom hücreleri potent osteoklast aktivatörlerini (ör., RANKL - Receptor Activator of Nuclear factor Kappa B Ligand) üreterek veya salınımlarını sağlayarak, doğrudan veya dolaylı olarak osteoklast formasyonunu veya aktivasyonunu arttırır. (2) Ayrıca kanda ve idrarda anormal proteinlerin varlı̆̆, nadiren tümör dokusu ve diğer organlarda amiloidin görülmesi de miyelom tanısında yardımcıdır. Plazmasitom (soliter miyelom) multipl miyelomun erken bir evresini temsil eder, çoğu olguda 5-20 yıl içinde miyelomun sistemik formuna dönüşür.

Miyelom sıklıkla 50 yaş üzeri erişkinlerin yaklaşık \%1'inde saptanabilen öncü bir lezyondan MGUS (Monoclonal Gammopathy of Unknown Significance) gelişir. ${ }^{[2]}$ Her yıl MGUS olgularının yaklaşık \%1'i miyeloma dönüşür. Miyelom hücreleri başlangıçta yüksek bir proliferasyon hızına sahip değildir, fakat hastalığın seyri sırasında artan sayıda kromozomal değişiklik meydana gelir. Başlangıçta hafifbulguların eşlik ettiği selim bir seyir izleyen hastalık zamanla hızlı ilerleyen agresif bir şekle dönüşür.

- İletişim adresi: Doç. Dr. Bülent Erol, Marmara Üniversitesi Pendik Eğitim Araştırma Hastanesi, Ortopedi ve Travmatoloji Kliniği, Pendik-Kaynarca, İstanbul Tel: 0216 - 62545 45, 0533 - 7205772 e-posta: bulerol@hotmail.com

- Geliș tarihi: 17 Haziran 2014 Kabul tarihi: 17 Haziran 2014 


\section{Klinik bulgular}

Miyelom genellikle 40 yaş üzerinde, en sık olarak da beşinci ve yedinci dekadlar arasında görülür. Daha genç yaş grubunda oldukça nadirdir ve bunlar genellikle plazmasitom (soliter miyelom) olgularını temsil eder. Durie ve Salmon tarafindan ortaya konan klinik evreleme sistemi immunoglobulin, kalsiyum ve paraprotein serum konsantrasyonları; üriner Bence-Jones proteininin atılımı; ve radyografilerde saptanan iskelet lezyonlarının sayısına dayanır. ${ }^{[1]}$ Bu sistem, sonradan beta-2microglobulin ve albümin serum seviyelerine dayanan prognostik bir indekse göre tekrar değerlendirilmiştir.

Miyelom primer olarak kırmızı ilik içeren kemiklerden köken alır ve bu nedenle en sık aksiyel iskelet tutulumu görülür. Fakat hastalık tüm kemiklerde kendini gösterebilir. Dirsek ve diz distalinde tutulum oldukça nadirdir. ${ }^{[3]}$ Hastaların büyük kısmında başlangıç bulgusu ağrıdır; ağrı genellikle hafif şiddette, geçici ve aktivite ile kötüleşen karakterdedir. Dolayısıyla, miyelom başlangıçta ağrı ile giden birçok selim süreçle karışabilir. Başlangıç bulguları hafif olabilmekle beraber hastalık zamanla agresif bir seyir gösterir. Patolojik kırıkla başvuru nadirdir fakat hastalık sürecinde patolojik kırık gelişimi göreceli olarak sık görülür (Şekil 1. a, b). Diğer birçok kemik kanserinden farklı olarak bulantı, kusma, kilo kaybı, halsizlik, ateş ve genel kemik ağrısı gibi sistemik bulgular klinik tabloya eşlik edebilir.

Miyelom primer olarak kemikten köken almakla beraber, matür $B$ hücrelerinin bir neoplazisi olması nedeniyle birçok organı etkiler. Hastalık ile ilişkili diğer sık görülen klinik özellikler; kemik iliğinin miyelom hücreleri ile replasmanı sonucu gelişen normositik, normokromik anemiyi; normal antikor üretiminde bozulmaya sekonder sık infeksiyon gelişimini; yaygın kemik destrüksiyonuna bağlı hiperkalsemiyi ve renal tübül obstrüksiyonu ile dolaşımdaki anormal proteinlerin hasarına bağı gelişen renal disfonksiyonu içerir.

Miyelomda monoklonal proliferasyon gösteren habis plazma hücreleri (miyelom hücreleri) spesifik bir immünoglobulin tipini üretir. Yüksek konsantrasyonda monoklonal immünoglobulin (en sık IgG [\%65], takiben IgA [\%20]) üretimi nedeniyle serum albümin - globulin oranı karakteristik olarak tersine döner. Serum immünelektroforezi monoklonal bir ağır zincir (\%83) ve hafif
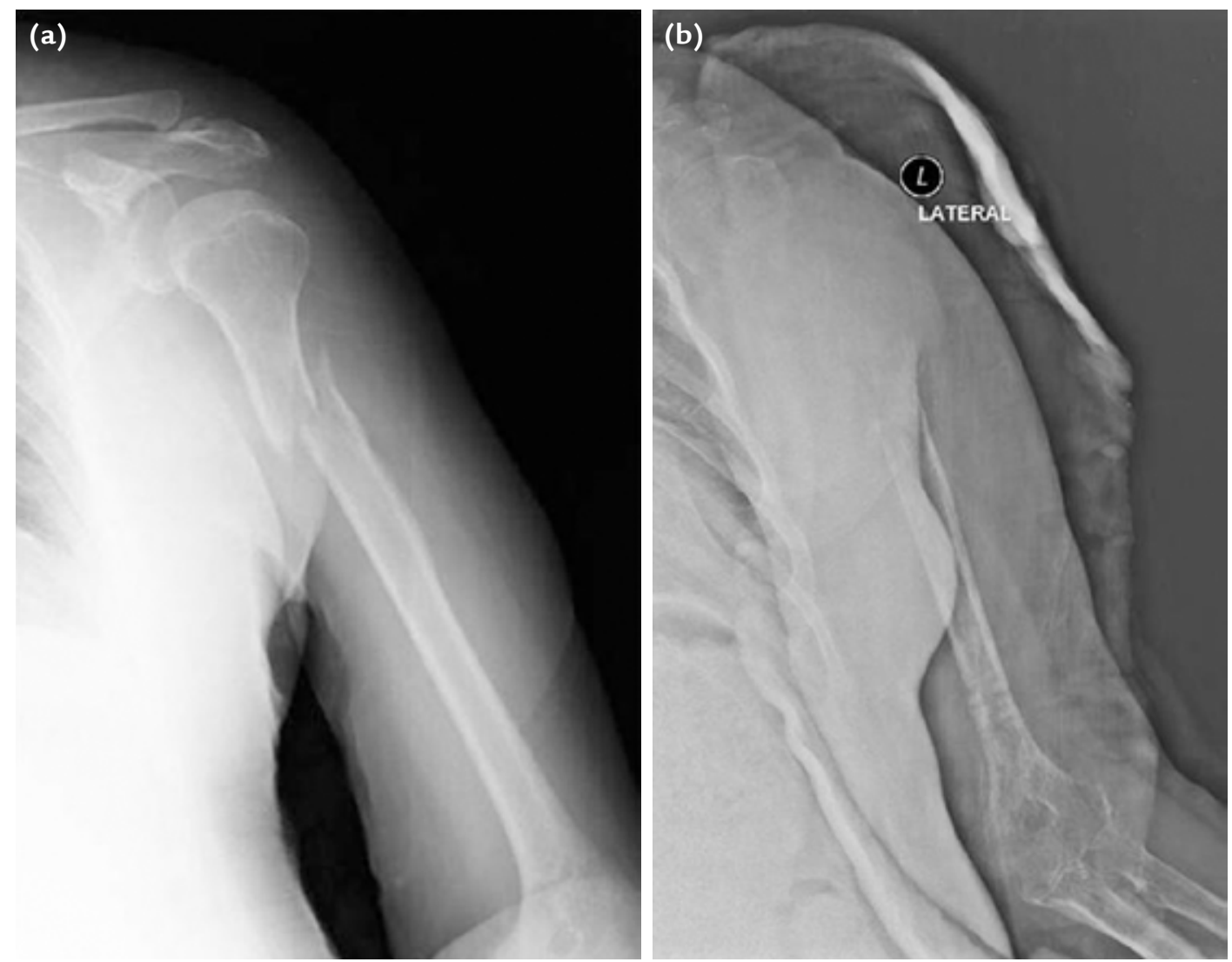

Şekil 1. a, b. Miyelom agresif bir seyir izleyebilir. Humerus proksimal diyafizinde patolojik kırık oluşturan lezyonun (a), birkaç aylık süre içinde çok hızlı bir seyir izleyerek tüm humerus proksimalini destrükte ettiği gözleniyor (b). 
zincir (\%8) baskınlığı gösterir. Monoklonal protein nedeniyle total immünoglobulin seviyesi yükselmekle beraber, normal serum immünoglobulin konsantrasyonları belirgin olarak azalır ve bu durum humoral immünitenin bozulmasına neden olur. Eğer hafif zincirler aşırı miktarda üretilirse, bunlar renal tübüllere geçer ve dimerize olarak idrarda Bence-Jones proteinlerini oluştururlar. ${ }^{[2]}$

\section{Radyolojik özellikler}

Miyelom radyografilerde faklı şekillerde prezente olabilir. Genellikle coğrafik tipte kemik destrüksiyonu oluşturan soliter bir lezyon veya çok sayıda küçük litik odaklar şeklinde görülür (Şekil 2). Kafatasında yuvarlak, zımba-deliği tarzında, benzer boyutlarda destrüksiyon alanları tipiktir. Omurgada yaygın osteoporoz izlenebileceği gibi, vertebral kolon boyunca çok sayıda litik lezyon görülebilir. Omurga tutulumu sonucu kompresyon kırıkları gelişebilir. Yassı ve uzun kemik tutulumunda medüller kemikte destrüksiyon alanları görülür ve bunlar ilerleyerek iç kortekste endosteal yenikliğe yol açar. Miyelomda, radyografilerde karakteristik olarak skleroz veya periosteal reaksiyon görülmez. ${ }^{[4]}$

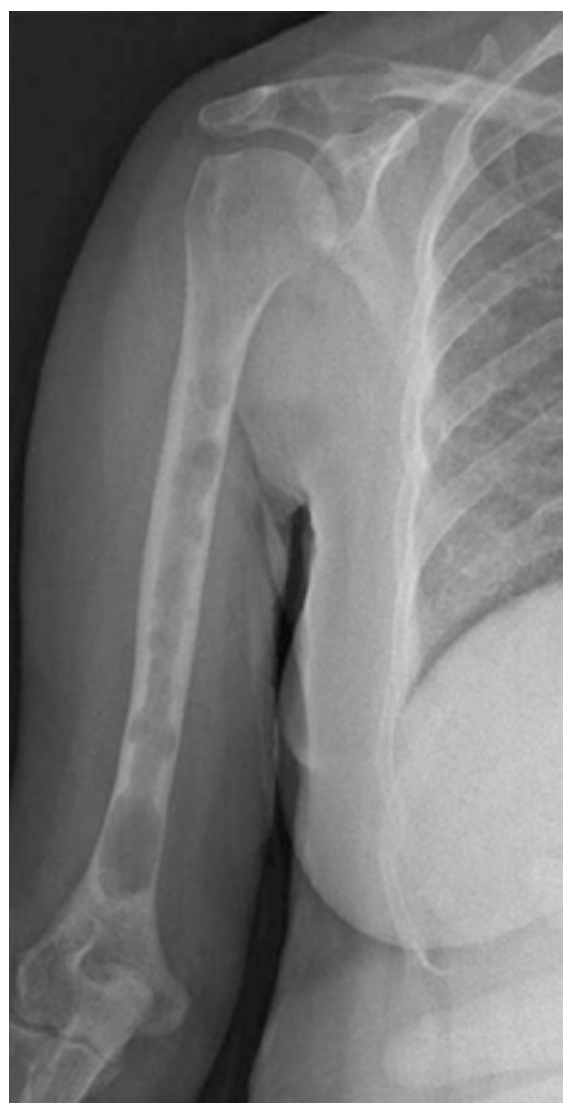

Multipl miyelomda sintigrafi genellikle normaldir. Nadiren, hiperemiye veya komşu kemikteki artmış dönüşüme/osteoblastik aktiviteye sekonder aktivite artışı gözlenebilir. Normal kemiğin radyofarmasötik ajanları tutmayan miyelom dokusuyla yer değiştirmesi sonucu, lezyonlar sintigrafide genellikle soğuk odak (negatif) şeklinde gözükür.

Bilgisayarlı tomografi (BT) tümörün intraosseöz yayılımını, kortikal destrüksiyonu ve ekstraosseöz komponenti radyografilere kıyasla daha iyi gösterir. Ayrıca radyografilerde görünmeyen bazı omurga lezyonları da BT ile saptanabilir. Manyetik rezonans (MR) görüntüleme, multipl miyelomdaki iskelet anormalliklerini göstermede radyografik incelemeden ve BT'den daha duyarlıdır. MR görüntüleme özellikle spinal lezyonları göstermede çok etkilidir. Miyelomda MR değişiklikleri yaygın veya fokal olabilir. Kemik lezyonları T1-ağırlıklı görüntülerde hipointens alanlar şeklinde izlenir ve çevre kemikle kontrast oluşturur. T2-ağırlıklı ve STIR (Short Time Inversion Recovery) görüntülerde ise lezyon homojen olarak yüksek sinyal yoğunluğundadır (Şekil 3. a-c). Hastalık kemik iliğinde belirgin yayılım göstermekle beraber tutulum homojen olmayabilir. Kemik iliğinin görünümü hastalığın yayılımına ve yağlı dokunun replasman derecesine bağlıdır. Yaşlı hastaların vertebralarında meydana gelen belirgin yağlı replasman lezyonları saklayabileceğinden yă̆-baskılı MR görüntüleri gerekebilir. ${ }^{[2]}$

\section{Radyolojik ayırıcı tanı}

Özellikle yaşlı hastalarda birçok kemikte litik lezyonların görülmesi durumunda multipl miyelom ve metastatik karsinom ilk akla gelen tanılardır. Radyonüklid kemik sintigrafisi bu iki sürecin ayrımında yararlıdır; metastatik karsinomda genellikle anormal sintigrafik bulgular izlenirken, miyelomda lezyonlar radyofarmasötik ajanları nadiren tutar. Tutulumun sık olduğu omurgada ise vertebral pedikül bulgusu tanıya yardımcı olabilir. Pediküller miyelomun geç evrelerinde etkilenirken, metastatik hastalıkta başlangıçtan itibaren aynı oranda korpus ve pedikül tutulumu vardır. ${ }^{[2]}$ Daha genç hastalarda hiperparatirodiye bağlı brown tümörler, poliostotik tipte fibröz displazi ve yine yaşlılarda ileri osteoporoz multipl miyelom ile karışabilir. Tek odakta destrüktif bir lezyon şeklindeki soliter miyelom ise dev hücreli kemik tümörü, diğer bazı primer habis kemik tümörleri (ör., malign fibröz histiyositom, fibrosarkom) ve soliter metastazlar ile karışabilir.

Şekil 2. Tüm humerus boyunca coğrafik tipte kemik destrüksiyonu oluşturan çok sayıda litik lezyon izleniyor. Suprakondiler bölgedeki medüller tutulumun ilerleyerek iç kortekste endosteal yenikliğe yol açtığı görülüyor. Multipl miyelomda lezyonlara karakteristik olarak periost reaksiyonu eşlik etmez. 

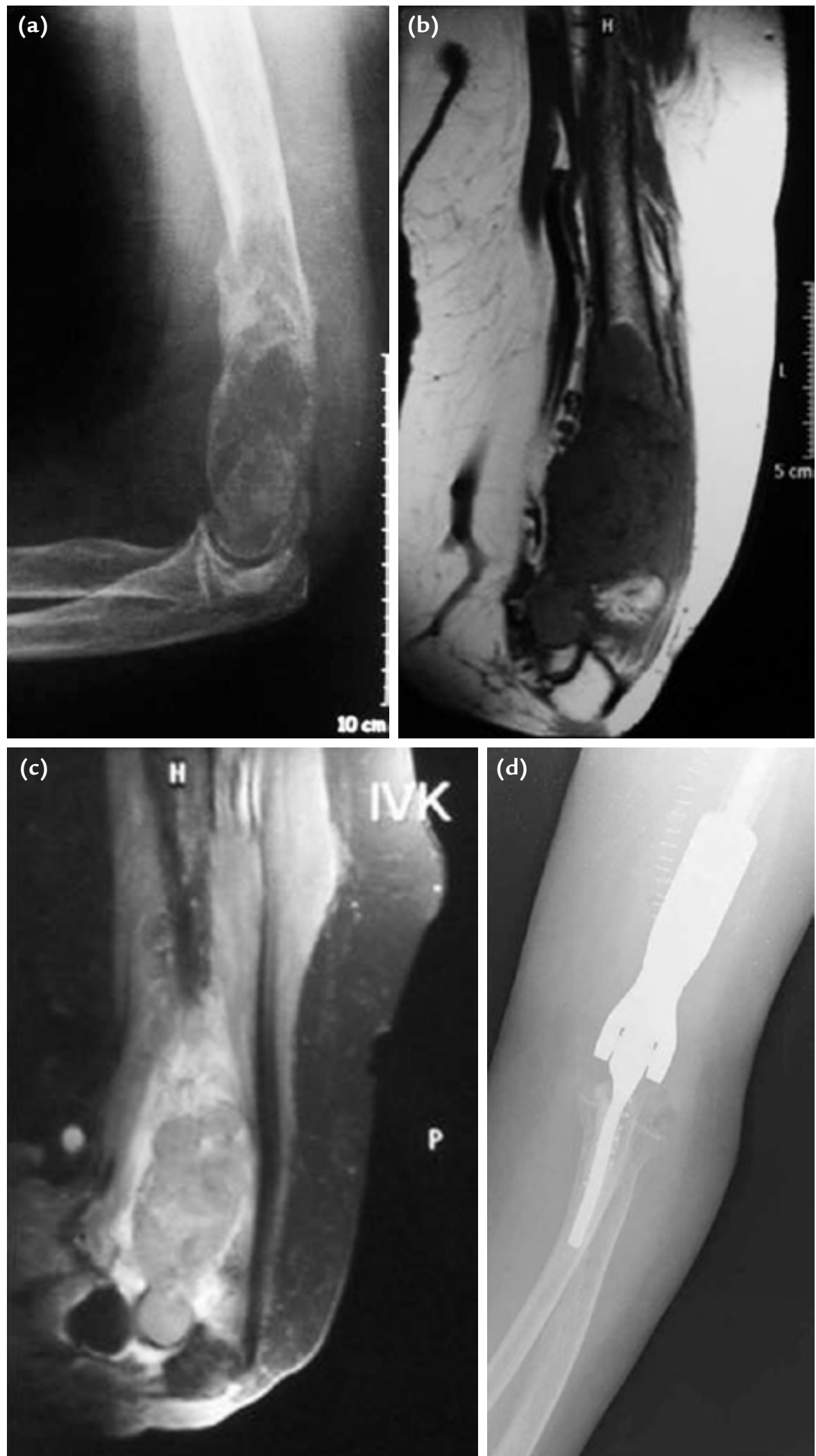

Şekil 3. a-d. Humerus distalinde yerleşmiş litik lezyona belirgin kortikal destrüksiyon ve patolojik kırığın eşlik ettiği izleniyor. MR görüntülemede lezyon T1-ağırlıklı sekanslarda hipointens, T2-ağırlıklı olanlarda ise hiperintens görünümdedir $(\mathbf{a}-\mathbf{c})$. Hastaya rezeksiyon ve endoprostetik rekonstrüksiyon uygulanmış (d). 


\section{Histopatolojik özellikler}

Miyelom tanısı için serum elektroforezi (monoklonal gammapatiyi ortaya koyar), iskelet taraması (survey) ve kemik iliği biyopsisi yeterlidir. Kemik lezyonunun biyopsisi tanı için nadiren gerekir.

Makroskopik olarak griden koyu kırmızıya değişen renkte yumuşak jelatinöz bir dokudur. Bu doku kemiği yaygın şekilde tutar, yuvarlak nodüller oluşturabilir veya ekstraosseöz uzanımı olan büyük kitlelere neden olabilir. Miyelomun mikroskopik görünümü karakteristiktir, normal yağlı ve hematopoetik iliği replase eden atipik plazma hücre tabakaları izlenir. Bu hücre tabakaları çevresinde matriks, fibröz doku veya reaktif kemik dokusu görülmez. ${ }^{[3]}$

\section{Tedavi}

Multipl miyelomun primer tedavisi kemoterapidir. Semptomatik kemik lezyonları radyoterapiye genellikle duyarlıdır ve hızlı cevap verir. Soliter miyelomda da lokal kontrol genellikle radyoterapi ile sağlanır. Patolojik kırık veya kırık riskinin olduğu durumlarda, ayrıca kemoterapi ve radyoterapiye dirençli, semptomatik lezyonların varlığında cerrahi tedavi gerekebilir. Cerrahinin amacı ağrıyı gidermek ve fonksiyonu arttırmaktır; internal tespit (+/- çimento ile güçlendirme), çimentolu hemiartroplasti/total eklem artroplastisi, daha nadiren rezeksiyon ve endoprostetik rekonstrüksiyon uygulanabilir (Şekil 3. d). Cerrahi stabilizasyon sonrası (yaklaşık üç hafta sonra yara iyileşmesini takiben) tutulan kemige adjuvan radyoterapi uygulanması önerilir.

Multipl miyelomda uzun dönem sağkalım nadirdir; hastaların çoğu tanıdan sonraki ilk üç yıl içinde ölür. Sistemik tutulum bulgusu olmayan (negatif kemik iliği biyopsisi, negatif iskelet taraması) soliter miyelomlu hastalarda prognoz daha iyidir. Olguların yarısından fazlası hastalığı takiben veya uzun bir hastalıksız dönem sonrası miyelomun sistemik formuna dönüşmekle beraber, bazı hastalar uzun bir hastalıksız dönem yaşayabilir, hatta çok azı devamlı olarak hastalıksız seyredebilir.

\section{(HABIS) KEMIK LENFOMASI}

Habis lenfoma, hücresel matürasyonun farklı evrelerindeki lenfoid hücrelerin oluşturduğu bir grup neoplaziye verilen isimdir ve kemiği primer veya sekonder olarak etkileyebilir. WHO'ya göre habis lenfomalar çeşitli alt gruplara ayrılmıştır:

a) iskeletin tek bölgesi tutulur ve buna bazen rejyoner lenf nodları eşlik edebilir,

b) lenf nodu veya viseral tutulum olmaksızın çok sayıda kemik tutulur, c) hastalık primer kemik tümörü şeklinde prezente olur fakat evreleme sırasında nodal ve viseral lezyonlar saptanır ve

d) bilinen lenfoma varlığında pozitif kemik biyopsisi elde edilir. ${ }^{[5]}$

Grup a ve b'de, yani evrelemede rejyoner lenf nodları hariç kemik dışı tutulum olmaması durumunda, hastalık primer kemik lenfoması şeklinde adlandırılır. Bazı otörler, kemik odağın tespitini takiben 6 ay süre ile nodal veya viseral tutulum olmamasını da primer kemik lenfoması olarak tanımlamıştır. Kemiğin hem primer hem de sekonder tutulumu non-Hodgkin lenfomada daha sıktır, Hodgkin lenfomaya bağlı tutulum nadir görülür.

Kemiğin primer non-Hodgkin lenfoması (primer kemik lenfoması) nadir bir tümördür ve tüm habis kemik tümörlerinin \%3-4'ünü oluşturur. Hastalık 2. ve 7. dekadlar arasında görülebilirken, en sık 35-45 yaş arasında rastlanır. ${ }^{[2]}$ Erkek kadın oranı yaklaşık 1,5:1'dir. Femur en sık tutulan kemiktir; bunu takiben pelvis, omurga ve kostalar gelir. Çoğu hasta lokalize ağrı ve şişlikten yakınır. Ateş, kilo kaybı, anemi ve yükselmiş eritrosit sedimentasyon hızı gibi sistemik bulgular eşlik edebilir. Ekstensif lokal hastalığa rağmen bazı lenfomalı hastaların kendilerini sağlıklı hissedebileceği ve tanıdan önce birkaç yıl boyunca asemptomatik/ minimal semptomatik seyredebileceği akılda tutulmalıdır. Patolojik kırıklar lenfomalı hastaların yaklaşık \%25'inde gözlenir. Omurga tutulumu olan hastalarda sinir kökü veya kord kompresyonuna bağlı nörolojik bulgular gelişebilir.

Lenfomalı hastaların başlangıç başvurularında ayrıntılı bir evreleme yapılmalıdır; evreleme çalışmaları, tam kan sayımı ve biyokimya, kemik sintigrafisi, gögüus/abdomen/pelvis BT ve kemik iliği biyopsisini içerir.

\section{Radyolojik ve histolojik özellikler}

Radyografilerde genellikle etkilenen kemiğin geniş bir kısmını veya tamamını içine alan ekstensif bir tutulum vardır. Lezyonun yayılımı ile hastanın klinik tablosu uyumsuz olabilir. Lenfomanın radyografik görünümündeki baskın özellik kemik destrüksiyonudur; genellikle permeatif veya güve-yeniği tarzında yıkım oluşturan kötü-sınırlı lezyonlar izlenir. Kortekste kalınlaşma olabilir fakat periosteal reaksiyon nadirdir.

Lenfomada kemik tutulumu genelde radyografilerde göründüğünden daha yaygındır (Şekil 4. a-d). Kemik sintigrafisi veya MR görüntülemedeki yaygın medüller tutuluma rağmen radyografiler tamamen normal olabilir. Lenfoma, kemik ağrısı ve normal radyografilere rağmen anormal sintigrafi ve $M R$ görüntüleme bulguları olan hastaların ayırıcı tanısında olmalıdır. 

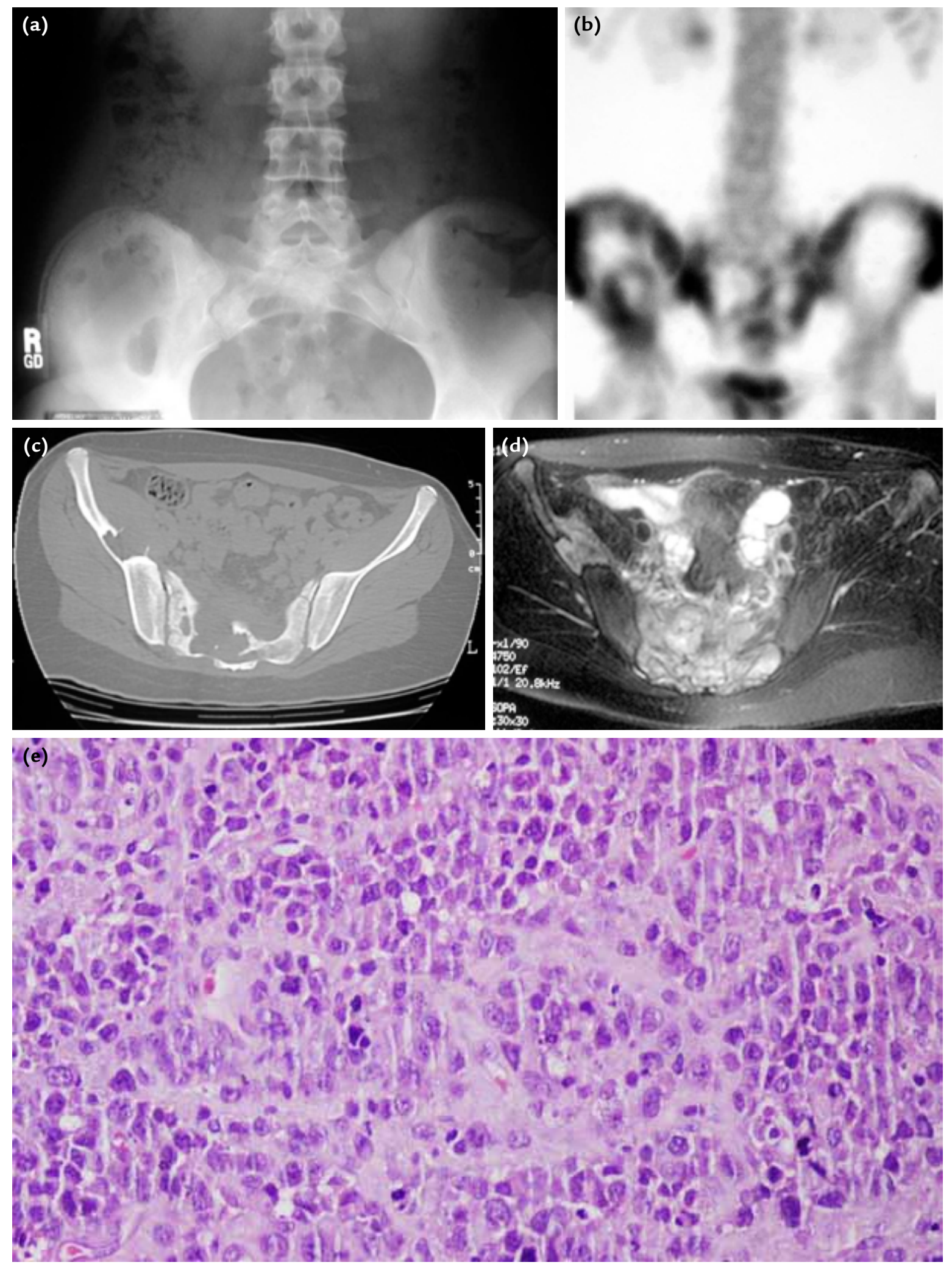

Şekil 4. a-e. illiak kanat ve sakrumu tutan tümörün radyografilerde belirgin bir bulgu vermediği (a), fakat sintigrafide bu bölgelerde aktivite artışının olduğu gözleniyor (b). BT kortikal destrüksiyonu ve lezyonun yumuşak doku yayılımını gösteriyor. (c). Tümöre bağlı intra- ve ekstraosseöz tutulum, birçok habis kemik neoplazisi gibi lenfomada da en iyi MR görüntüleme ile ortaya konabilir (d). Histopatolojik incelemede kemik iliğini dolduran habis lenfoid hücre kümeleri izleniyor (e). 
Teknetium-metilen difosfonat ve gallium kemik sintigrafilerinde lezyon bölgelerinde artmış radyoizotop tutulumu görülür. BT, kemik destrüksiyonunu göstermesinin yanı sıra lezyonun yumuşak dokuya yayılımını da ortaya koyabilir; özellikle aksiyel iskelet tutulumunda yararlıdır. MR görüntüleme, kemik iliği ve yumuşak doku yayılımını en iyi ortaya koyan inceleme yöntemidir. T1-ağırlıklı görüntülerde tümöre bağlı yaygın infiltrasyon düşük sinyal yoğunluğunda bir alan şeklinde izlenir. T2-ağırlıklı görüntülerde ise etkilenen alan kasa göre hiperintens, yağa göre izointens görünümdedir.

Lenfomanın radyolojik ayırıcı tanısında diğer habis kemik tümörleri yer alır. Hastanın yaşı önemlidir; küçük çocuklarda (<10 yaş) metastatik nöroblastom, daha büyük çocuklarda ve genç erişkinlerde Ewing sarkomu, 40-50 yaş üzerindeki hastalarda ise metastatik karsinom ve miyelom ayırıcı tanıda ilk akla gelen tümörlerdir. Osteomiyelit tüm yaş gruplarında lenfoma ile karışabilir. ${ }^{[2]}$

Histolojik olarak lenfomaların görünümü farklılık gösterebilir. Lezyon genellikle kemik iliğini dolduran habis lenfoid hücre kümeleri içerir (Şekil 4. e). Primer non-Hodgkin lenfomada, küçük lenfositik hücreler ve daha büyük histiyositik hücrelerin karışımından oluşan diffüz bir büyüme paterni izlenir. Sekonder lenfomalar ise paratrabeküler, nodüler, interstisyel ve diffüz infiltrasyon paternleri gösterir. Primer non-Hodgkin lenfomadaki hücreler genellikle yuvarlak, ovoid ve pleomorfiktir. Lenfomanın histolojik ayıııı tanısında başta Ewing sarkomu olmak üzere kemiği tutan diğer küçük, yuvarlak hücreli tümörler yer alır. Immünhistokimya çalışmaları (ör., lenfoid belirteçler) ayırıcı tanıda yardımcıdır.

\section{Tedavi}

Lenfomanın primer tedavisi sistemik multi-ajan kemoterapidir. Radyoterapi hasta eğer kemoterapiye tam yanıt vermemişse lokal kontrol için kullanılabilir. Lenfoma tedavisinde cerrahinin sınırlı bir rolü vardır ve primer olarak tedavide değil tanıda gerekli olur. Fakat uzun kemiklerde belirgin destrüksiyon oluşturan lezyonlar patolojik kırık veya kırık riski meydana getirdiğinde, internal tespit veya segmental rezeksiyon ve endoprotez uygulaması endike olabilir. ${ }^{[3]}$ Cerrahi tedavi kemoterapi ve radyoterapi ile, ameliyat öncesi ve/veya sonrası kombine edilir. Primer kemik lenfomalı hastalar, sistemik hastalığı olanlara kıyasla daha iyi bir prognoza sahiptir (yaklaşık \% 55 beş yıllık sağkalıma kıyasla yaklaşık \%25 beş yıllık sağkalım).[ ${ }^{[1]}$

\section{LÖSEMi}

Akut lösemi çocukluk çağının en sık kanseridir. Akut lenfoblastik lösemi olguların \%80'ini oluşturur ve $2-5$ yaşları arasında zirve yapar. Akut lenfoblastik lösemili hastalarda kemik ve eklem tutulumu sıktır ve bu çocuklar sıklıkla kemik veya eklem ağrısı ile başvurabilirler. Kemik ağrısına sitopeni, ateş, kanama bulguları, hepatosplenomegali veya lenfadenopati eşlik ettiğinde lösemik kemik tutulumundan şüphelenilmelidir. Akut lösemili çocuklarda diffüz osteopeni sıktır. Buna medüller kavite veya kortekste litik lezyonlar, radyolüsan metafizyel bantlar ('lösemi çizgileri') ve periosteal yeni kemik oluşumu eşlik edebilir (Tablo 1 ) (Şekil 5. a-d). ${ }^{[6]}$ Tanı, kemik iliği aspirasyon spesimeninde tipik lösemik blastların görülmesi ile konur. Löseminin tedavisi uzun süreli multi-ajan kemoterapiyi içerir. Akut lenfoblastik lösemide ortalama sağkalım oranı \%70'e ulaşır.

Tablo 1. Löseminin kas-iskelet sistemi bulguları

\begin{tabular}{|c|c|}
\hline Klinik & Radyografik \\
\hline \multirow{8}{*}{$\begin{array}{l}\text { - Kas-iskelet ağrısı } \\
\text { - Kemik ağrısı: aralıklı, lokalize, keskin, şiddetli ve ani başlangıçlı } \\
\text { - Eklem ağrısı: gezici }\end{array}$} & - Yaygın osteopeni: protein ve mineral metabolizmasında değişiklikler. \\
\hline & $\begin{array}{l}\text { - Radyolüsan metafizyel bantlar (genellikle ilk radyografik anormallik): } \\
\text { epifizyel büyüme plağının bozulmuş osteojenezi. }\end{array}$ \\
\hline & $\begin{array}{l}\text { - Periosteal kemik oluşumu: lösemik infiltrasyon periostu kemik } \\
\text { korteksten kaldırı. }\end{array}$ \\
\hline & $\begin{array}{l}\text { - Osteolitik lezyonlar: kemik iliğinin lösemik infiltrasyonu, lokal } \\
\text { kanama ve komşu trabeküler kemiğin osteonekrozu. }\end{array}$ \\
\hline & - Osteosekleroz: geç bulgu. \\
\hline & $\begin{array}{l}\text { - Karışık lezyonlar: bir alanda osteoblastlar tarafindan kemik üretimi } \\
\text { ve aynı anda diğer bir alanda artmış osteoklastik aktivite. }\end{array}$ \\
\hline & - Permeatif patern: hızlı büyüyen agresif bir lezyonu gösterir. \\
\hline & $\begin{array}{l}\text { - Patolojik kırık: en sık omurganın osteoporozu ile beraberdir, bunun } \\
\text { yanı sıra başka bölgelerde minör travma sonucu oluşur. }\end{array}$ \\
\hline
\end{tabular}



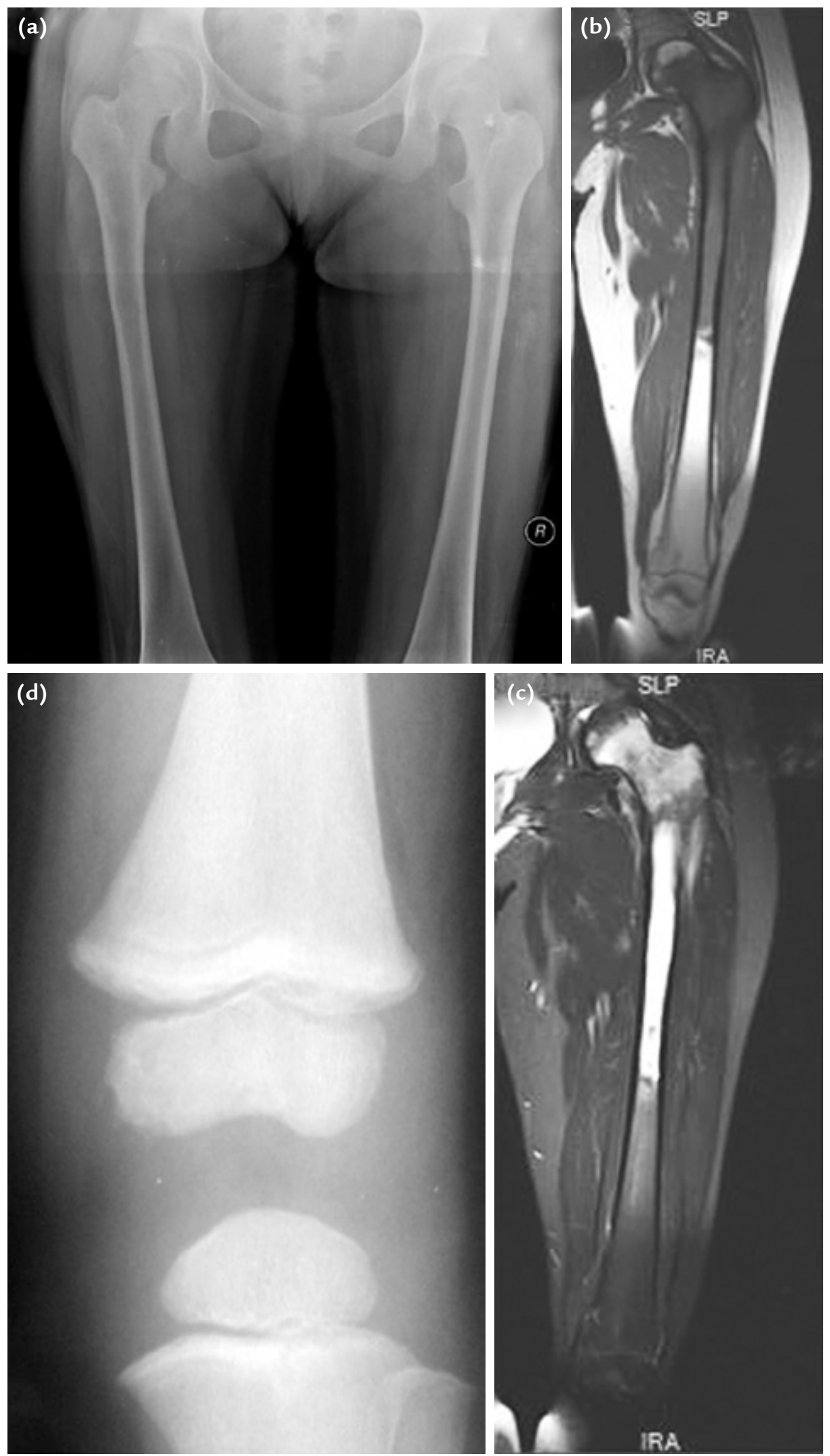

Şekil 5. a-d. On dört yaşında akut lenfoblastik lösemili bir hastanın proksimal femurundaki lösemik tutulum radyografi ve MR görüntülemede izleniyor $(a-c)$. Bir başka çocukta radyolüsan metafizyel bantlar görülüyor (d). 


\section{KAYNAKLAR}

1. Heck Jr R. Malignant tumors of bone. In: Canale ST, Beaty $\mathrm{JH}$, editors. Campbell's Operative Orthopaedics, 11th ed. Philadelphia: Mosby Elsevier; 2008. p.901-38.

2. Greenspan A, Jundt G, Remagen W. Differential diagnosis in orthopaedic oncology, 2nd ed. Philadelphia, PA: Lippincott Williams \& Wilkins; 2007.

3. Campanacci M. Bone and soft tissue tumors, 2nd ed. Wien, New York: Springer-Verlag; 1999.
4. Schwartz HS, editor. Orthopaedic Knowledge Update (OKU): Musculoskeletal tumors, 2nd ed. Rosemonth, IL: AAOS Publication; 2007.

5. Fletcher CDM, Unni KK, Mertens F, editors. World Health Organization Classification of Tumors. Pathology and Genetics of Tumors of Soft Tissue and Bone. Lyon: IARC Press; 2002.

6. Erol B, States L, Pawel BR, Tamai J, Dormans JP. Musculoskeletal tumors in children. In: Dormans JP, editor. Pediatric orthopaedics and sports medicine: the requisites in pediatrics. St. Louis (MO): Mosby; 2004. p.299-336. 